Руденська Г. В.;

Педан Ф. П.;

Ткаченко М. В., к.Т.н.

Центр воєнно-стратегічних досліджень Національного університету оборони України імені Івана Черняховського

\title{
Використання системи ключових показників при оцінці фінансового забезпечення Збройних Сил України
}

Резюме. На основі тестових даних проведено розрахунок інтеграційного показника щодо оцінки фінансово-економічної діяльності Збройних Сил України і дана якісна інтерпретація отриманим результатам.

Ключові слова: ключові показники, адитивно-мультиплікативна модель, інтеграційний показник, оцінка, фінансово-економічна діяльність.

Постановка проблеми. Для прийняття обгрунтованих рішень щодо ефективного фінансування діяльності Збройних Сил України (3С України) у відповідних структурних підрозділах Міністерства оборони України для вищого керівництва формується звіт, який містить інформацію про структуру витрат, видатки за бюджетними програмами. При цьому дані подаються у вигляді "заплановані фінансові ресурси" i “надходження фактичних коштів”, а також різниці між ними. Також висвітлюються дані про кредиторську i дебіторську заборгованість, оперативні і капітальні видатки. Вказані показники виражаються через загальний та спеціальний фонди у натуральному виразі та у відсотках. Проте, немає можливості відстежувати у динаміці процеси планування та витрачання оборонного бюджету.

Аналіз останніх досліджень i публікацій. В роботах [1-5] визначені проблемні питання в галузі планування та витрачання оборонного бюджету та шляхи їх подолання. Однак питання оперативної оцінки фінансового стану ЗС України не висвітлені і залишаються актуальними.

Мета статті. На основі демонстраційного прикладу довести адекватність розрахунків щодо оцінки фінансового забезпечення Збройних Сил України, використовуючи запропоновані ключові показники.

Виклад основного матеріалу. Забезпечення ефективності планування, розподілу і використання фінансових ресурсів - головна ціль функціонування фінансових органів МО України та ЗС України. Для оцінки фінансового забезпечення ЗС України будемо використовувати ключові показники, що були висвітлені у [6]. Для кожного рівня управління фінансово-економічною діяльністю були визначені ціль ефективного функціонування та показники, що характеризують фінансово-економічну діяльність. Після чого була здійснена прив'язка показників до відповідних цілей розпорядників коштів на кожному рівні ієрархії та на основі експертних оцінок розраховано рівень питомої ваги (визначення впливу один на одного) для кожного показника. 3 метою нівелювання великого розкиду в оцінках впливу показників один на одного було розраховано середне геометричне для кожного показника та приведено до одної шкали вимірювання.

Інтегральний показник визначено на основі багаторівневої адитивномультиплікативної моделі оцінки узагальнених показників $[7,8]$, вибір якої обумовлено залежністю показників на всіх рівнях каскадування.

Наведемо приклад розрахунку для сфери "Забезпечення фінансовими ресурсами ЗС України”, напряму 2.1. Достатня наявність фінансових ресурсів для забезпечення життєдіяльності 3С України. Для оцінки напряму 2.1 використовуються 10 показників, які наведені у Табл. 1.

Розрахунок показників буде проводитись для ситуації нерівномірного фінансування життєдіяльності ЗС України на протязі певного року. Сценарій розрахунку пропонується наступний: в перші місяці (січень, лютий) здійснюється суттєве недофінансування, в наступні місяці (березень, квітень) - незначне пере фінансування (тобто компенсація за попередні місяці), потім фінансування здійснюється у припустимих межах, але 
дефіцит коштів накопичується, який на при кінці року покривається значним пере фінансуванням.

При цьому значення показників, що пов'язані 3 дебіторською та кредиторською заборгованостями знаходяться у припустимих встановлених межах, а ті, що повинні знижуватись - на протязі року зменшуються. Значення інших показників, що пов'язані 3 виконанням бюджету іноді не будуть знаходитись у припустимих межах. При цьому будуть використані тестові дані (див. Табл. 211).

Таблиця 1

Перелік показників ефективності фінансового забезпечення ЗС України

\begin{tabular}{|c|c|l|}
\hline № & \multicolumn{2}{|c|}{ Назва та символ показника } \\
\hline 1. & $\mathbf{q}_{\mathbf{1}}$ & Коефіцієнт дебіторської простроченої заборгованості \\
\hline 2. & $\mathbf{q}_{\mathbf{2}}$ & Коефіцієнт кредиторської простроченої заборгованості \\
\hline 3. & $\mathbf{q}_{\mathbf{3}}$ & Коефіцієнт безнадійної дебіторської заборгованості \\
\hline 4. & $\mathbf{q}_{\mathbf{4}}$ & Коефіцієнт покриття кредиторської заборгованості \\
\hline 5. & $\mathbf{q}_{\mathbf{7}}$ & Коефіцієнт своєчасності погашення кредиторської заборгованості \\
\hline 6. & $\mathbf{q}_{\mathbf{8}}$ & Коефіцієнт виконання кошторису ЗФ \\
\hline 7. & $\mathbf{q}_{\mathbf{1 0}}$ & Коефіцієнт дефіциту ЗФ \\
\hline 8. & $\mathbf{q}_{11}$ & Відносний показника відхилення суми фактичного фінансування від планового \\
\hline 9. & $\mathbf{q}_{12}$ & Показник витрачання бюджету \\
\hline 10. & $\mathbf{q}_{13}$ & Показник відхилення суми кошторисних призначень від суми потреби \\
\hline
\end{tabular}

Коефіціснт дебіторської простроченої заборгованості

Таблиця 2

\begin{tabular}{|c|c|c|c|c|c|c|c|c|c|c|c|c|}
\hline & \multicolumn{10}{|c|}{ Місяці } \\
\hline & I & II & \multicolumn{1}{|c|}{ III } & \multicolumn{1}{|c|}{ IV } & \multicolumn{1}{|c|}{ V } & VI & VII & VIII & IX & X & XI & XII \\
\hline ДЗпр & 113,4 & 153,3 & 275,6 & 423,5 & 543,9 & 674,6 & 743,6 & 899,1 & 960,7 & 1002,5 & 1087,2 & 1154,5 \\
\hline ДЗ & 374,2 & 743,6 & 1487,3 & 2111,6 & 2783,6 & 3156,6 & 3465,3 & 3788,0 & 4006,8 & 4154,4 & 4265,5 & 4301,5 \\
\hline q $_{1}<0,3$ & $\mathbf{0 , 3 0}$ & $\mathbf{0 , 2 1}$ & $\mathbf{0 , 1 9}$ & $\mathbf{0 , 2 0}$ & $\mathbf{0 , 2 0}$ & $\mathbf{0 , 2 1}$ & $\mathbf{0 , 2 1}$ & $\mathbf{0 , 2 4}$ & $\mathbf{0 , 2 4}$ & $\mathbf{0 , 2 4}$ & $\mathbf{0 , 2 5}$ & $\mathbf{0 , 2 7}$ \\
\hline
\end{tabular}

Д3

ДЗ - дебіторська заборгованість

Таблиця 3

Коефіцієнт простроченої кредиторської заборгованості

\begin{tabular}{|c|c|c|c|c|c|c|c|c|c|c|c|c|}
\hline & \multicolumn{10}{|c|}{ Місяці } \\
\hline & I & II & III & IV & V & VI & VII & VIII & IX & X & XI & XII \\
\hline КЗпр & 113 & 102 & 89 & 81 & 72 & 61 & 45 & 34 & 24,5 & 17 & 11 & 7 \\
\hline КЗ & 354 & 334 & 324 & 301 & 287 & 267 & 254 & 248 & 230,1 & 221 & 201 & 189 \\
\hline q $_{2} \downarrow$ & $\mathbf{0 , 3 1 9}$ & $\mathbf{0 , 3 0 5}$ & $\mathbf{0 , 2 7 5}$ & $\mathbf{0 , 2 6 9}$ & $\mathbf{0 , 2 5 1}$ & $\mathbf{0 , 2 2 8}$ & $\mathbf{0 , 1 7 7}$ & $\mathbf{0 , 1 3 7}$ & $\mathbf{0 , 1 0 6}$ & $\mathbf{0 , 0 7 7}$ & $\mathbf{0 , 0 5 5}$ & $\mathbf{0 , 0 3}$ \\
\hline
\end{tabular}

КЗпр - прострочена кредиторська заборгованість

К3 - кредиторська заборгованість

$\mathrm{q}_{2} \downarrow$ - зменшення від фіксованого значення

Таблиця 4

Коефіціснт безнадійної дебіторської заборгованості

\begin{tabular}{|l|c|c|c|c|c|c|c|c|c|c|c|c|}
\hline & \multicolumn{10}{|c|}{ Місяці } \\
\hline & I & II & III & IV & V & VI & VII & VIII & IX & X & XI & XII \\
\hline ДЗбн & 9,7 & 8,9 & 8,1 & 7,3 & 6,5 & 5,7 & 4,9 & 4,1 & 3,3 & 2,5 & 1,7 & 0,9 \\
\hline ДЗ & 374,2 & 743,6 & 1487,3 & 2111,6 & 2783,6 & 3156,6 & 3465,3 & 3788,0 & 4006,8 & 4154,4 & 4265 & 4301 \\
\hline $\mathrm{q}_{3} \downarrow$ & $\mathbf{0 , 0 2 5 9}$ & $\mathbf{0 , 0 1 2 0}$ & $\mathbf{0 , 0 0 5 4}$ & $\mathbf{0 , 0 0 3 5}$ & $\mathbf{0 , 0 0 2 3}$ & $\mathbf{0 , 0 0 1 8}$ & $\mathbf{0 , 0 0 1 4}$ & $\mathbf{0 , 0 0 1 1}$ & $\mathbf{0 , 0 0 0 8}$ & $\mathbf{0 , 0 0 0 6}$ & $\mathbf{0 , 0 0 0}$ & $\mathbf{0 , 0 0 0 2}$ \\
\hline
\end{tabular}

ДЗбн - списана (безнадійна) дебіторська заборгованість

Д3 - дебіторська заборгованість

$\mathrm{q}_{3} \downarrow$ - зменшення від фіксованого значення

Таблиця 5

Коефіцієнт покриття кредиторської заборгованості

\begin{tabular}{|c|c|c|c|c|c|c|c|c|c|c|c|c|}
\hline & \multicolumn{12}{|c|}{ Місяці } \\
\hline & I & II & III & IV & V & VI & VII & VIII & IX & X & XI & XII \\
\hline $3 a$ & 352 & 35 & 324 & 303 & 290 & 269 & 255 & 248,3 & 235 & 224 & 205 & 191 \\
\hline K3 & 354 & 334 & 324 & 301 & 287 & 267 & 254 & 248 & 230,1 & 221 & 201 & 189 \\
\hline $4 \geq 1$ & 0,994 & 1,063 & 1,000 & 1,007 & 1,010 & 1,007 & 1,004 & 1,001 & 1,021 & 1,014 & 1,020 & 1,01 \\
\hline
\end{tabular}

ЗалКошт - залишки кошторисних призначень

К3 - кредиторська заборгованість 
Значення показника за перший місяць пояснюється недофінансуванням на початку року за сценарієм, значення показника за другий місяць у порівнянні з іншими значеннями більше за рахунок перефінансування.

Таблиця 6

Коефіціснт свосчасності погашення кредиторської заборгованості

\begin{tabular}{|l|r|r|r|r|r|r|r|r|r|r|r|r|}
\hline & \multicolumn{10}{|l|}{ Місяці } \\
\hline & \multicolumn{1}{|l|}{ I } & \multicolumn{1}{l|}{ II } & III & IV & V & VI & VII & VIII & IX & X & XI & XII \\
\hline ЗаЛ Коштр & 45 & 55 & 34 & 44 & 56 & 45 & 41 & 34 & 32,5 & 35 & 44 & 41 \\
\hline К3 & 354 & 334 & 324 & 301 & 287 & 267 & 254 & 248 & 230,1 & 221 & 201 & 189 \\
\hline $\mathrm{q}_{7}=0,1-0,25$ & $\mathbf{0 , 1 2 7}$ & $\mathbf{0 , 1 6 5}$ & $\mathbf{0 , 1 0 5}$ & $\mathbf{0 , 1 4 6}$ & $\mathbf{0 , 1 9 5}$ & $\mathbf{0 , 1 6 9}$ & $\mathbf{0 , 1 6 1}$ & $\mathbf{0 , 1 3 7}$ & $\mathbf{0 , 1 4 1}$ & $\mathbf{0 , 1 5 8}$ & $\mathbf{0 , 2 1 9}$ & $\mathbf{0 , 2 1}$ \\
\hline
\end{tabular}

Зал коштр - залишки коштів на рахунках

К3 - кредиторська заборгованість

Таблиця 7

Коефіціснт виконання кошторису загального фонду

\begin{tabular}{|c|c|c|c|c|c|c|c|c|c|c|c|c|}
\hline & \multicolumn{10}{|c|}{ Місяці } \\
\hline & I & II & III & IV & V & VI & VII & VIII & IX & X & XI & XII \\
\hline Надх & 1374 & 5505 & 4057 & 4423 & 4407 & 4301 & 4313 & 4356 & 4231 & 4988 & 6510 & 6256 \\
\hline Кошт & 1465 & 5211 & 4176 & 4567 & 4510 & 4300 & 4378 & 4356 & 4234 & 4988 & 6300 & 5888 \\
\hline $\mathrm{q}_{8}=0,9-1$ & $\mathbf{0 , 9 4}$ & $\mathbf{1 , 0 6}$ & $\mathbf{0 , 9 7}$ & $\mathbf{0 , 9 7}$ & $\mathbf{0 , 9 8}$ & $\mathbf{1 , 0 0}$ & $\mathbf{0 , 9 9}$ & $\mathbf{1 , 0 0}$ & $\mathbf{1 , 0 0}$ & $\mathbf{1 , 0 0}$ & $\mathbf{1 , 0 3}$ & $\mathbf{1 , 0 6}$ \\
\hline
\end{tabular}

Надх - виділені асигнування (розподіл фінансування) на момент формування звіту

Кошт - кошторисні призначення на рік з урахуванням змін

За сценарієм в перший місяць недофінансування (на 0,6); в наступний місяць здійснюється компенсація за попередній - перефінансування. В наступні місяці також спостерігається не велике недофінансування (в межах 0,01-0,03), яке компенсується на при кінці року.

Таблиця 8

Коефіціснт дефіциту загального фонду

\begin{tabular}{|l|l|r|r|r|r|r|r|r|r|r|r|r|}
\hline & \multicolumn{10}{|c|}{ Місяці } \\
\hline & I & \multicolumn{1}{|c|}{ II } & \multicolumn{1}{|c|}{ III } & \multicolumn{1}{l|}{ IV } & V & VI & VII & VIII & IX & X & XI & XII \\
\hline Надх & 1304 & 5805 & 4057 & 4423 & 4407 & 4301 & 4313 & 4356 & 4231 & 4988 & 6510 & 6256 \\
\hline Потр & 1515 & 5543 & 4277 & 4634 & 4591 & 4357 & 4411 & 4465 & 4244 & 4999 & 6411 & 6101 \\
\hline q $_{10}=0,75-1$ & $\mathbf{0 , 8 6}$ & $\mathbf{1 , 0 5}$ & $\mathbf{0 , 9 5}$ & $\mathbf{0 , 9 5}$ & $\mathbf{0 , 9 6}$ & $\mathbf{0 , 9 9}$ & $\mathbf{0 , 9 8}$ & $\mathbf{0 , 9 8}$ & $\mathbf{1 , 0 0}$ & $\mathbf{1 , 0 0}$ & $\mathbf{1 , 0 2}$ & $\mathbf{1 , 0 3}$ \\
\hline
\end{tabular}

Надх - виділені асигнування (розподіл фінансування) на момент формування звіту

Потр річ - плановий показник видатків

Як правило, потреба завжди перебільшує надходження, що і відображено у таблиці. Однак, значення коефіцієнту також показують нерівномірність фінансування на початку і на при кінці року.

Таблиця 9

Відносний показника відхилення суми фактичного фінансування від планового

\begin{tabular}{|c|c|c|c|c|c|c|c|c|c|c|c|c|}
\hline & \multicolumn{12}{|c|}{ Місяці } \\
\hline & I & II & III & IV & $\mathrm{V}$ & VI & VII & VIII & IX & $X$ & XI & XII \\
\hline Надх & 1421 & 5385 & 4057 & 4423 & 4457 & 4301 & 4313 & 4356 & 4231 & 4988 & 6510 & 6056 \\
\hline Кошт & 1465 & 5211 & 4126 & 4527 & 4510 & 4300 & 4378 & 4356 & 4234 & 4988 & 6300 & 5888 \\
\hline $\mathrm{q}_{11}$ & 3,00 & $-3,00$ & 2,00 & 2,00 & 1,00 & 0,00 & 1,00 & 0,00 & 0,00 & 0,00 & $-3,00$ & $-3,00$ \\
\hline
\end{tabular}

Актуально при розбіжності сум фактичного фінансування від річних кошторисних призначень

Надх - виділені асигнування (розподіл фінансування) на момент формування звіту

Кошт - кошторисні призначення на рік з урахуванням змін

В ідеальному випадку коефіцієнт повинен дорівнювати 0, тобто суми надходження відповідають кошторисним призначенням. Позитивний відсоток характеризує недофінансування, а негативний - перефінансування.

Таблиця 10

Показник витрачання бюджету

\begin{tabular}{|c|c|c|c|c|c|c|c|c|c|c|c|c|}
\hline & \multicolumn{10}{|c|}{ Місяці } \\
\hline & I & II & III & IV & V & VI & VII & VIII & IX & X & XI & ХII \\
\hline Витр & 1465 & 5211 & 4176 & 4567 & 4510 & 4300 & 4378 & 4356 & 4234 & 4988 & 6300 & 6256 \\
\hline Надх & 1465 & 5211 & 4176 & 4567 & 4510 & 4300 & 4378 & 4356 & 4234 & 4988 & 6300 & 5888 \\
\hline q $_{12}=1$ & $\mathbf{1 , 0 0}$ & $\mathbf{1 , 0 0}$ & $\mathbf{1 , 0 0}$ & $\mathbf{1 , 0 0}$ & $\mathbf{1 , 0 0}$ & $\mathbf{1 , 0 0}$ & $\mathbf{1 , 0 0}$ & $\mathbf{1 , 0 0}$ & $\mathbf{1 , 0 0}$ & $\mathbf{1 , 0 0}$ & $\mathbf{1 , 0 0}$ & $\mathbf{1 , 0 6}$ \\
\hline
\end{tabular}

Витр - витрачені фінансові ресурси

Надх - виділені асигнування (розподіл фінансування) на момент формування звіту

Даний показник повинен дорівнювати одиниці, однак на при кінці року він перевищує установлену норму, що характеризує значне пере фінансування. 
Таблиця 11

Показник відхилення суми кошторисних призначень від суми потреби

\begin{tabular}{|c|c|c|c|c|c|c|c|c|c|c|c|c|}
\hline & \multicolumn{10}{|c|}{ Місяці } \\
\hline & I & II & III & IV & V & VI & VII & VIII & IX & X & XI & XII \\
\hline Кошт & 1465 & 5211 & 4176 & 4567 & 4510 & 4300 & 4378 & 4356 & 4234 & 4988 & 5888 & 6300 \\
\hline Потр рі4 & 1515 & 5543 & 4277 & 4634 & 4591 & 4357 & 4411 & 4465 & 4244 & 4999 & 6411 & 6101 \\
\hline q $_{13}=1$ & $\mathbf{0 , 9 7}$ & $\mathbf{0 , 9 4}$ & $\mathbf{0 , 9 8}$ & $\mathbf{0 , 9 9}$ & $\mathbf{0 , 9 8}$ & $\mathbf{0 , 9 9}$ & $\mathbf{0 , 9 9}$ & $\mathbf{0 , 9 8}$ & $\mathbf{1 , 0 0}$ & $\mathbf{1 , 0 0}$ & $\mathbf{0 , 9 2}$ & $\mathbf{1 , 0 3}$ \\
\hline
\end{tabular}

Кошт - кошторисні призначення на рік з урахуванням змін

Потр річ - плановий показник видатків

Потреба у фінансових ресурсах, як правило, перевищує кошторисні призначення, що i відображено у таблиці 11, крім останнього місяця, коли здійснюється перефінансування.

Значення інтегрального показника (рис. 1)

Таблиця 12

\begin{tabular}{|c|c|c|c|c|c|c|c|c|c|c|c|c|}
\hline & \multicolumn{10}{|c|}{ Мiсяці } \\
\hline & I & II & III & IV & V & VI & VII & VIII & IX & X & XI & XII \\
\hline $\mathbf{Q}$ & 0,8096 & 0,1713 & 0,6979 & 0,7012 & 0,5920 & 0,4862 & 0,5905 & 0,4782 & 0,4812 & 0,4796 & 0,1495 & 0,1702 \\
\hline Стан & Поган & Поган & Задов. & Поган & Задов. & Добре & Задов. & Добре & Добре & Добре & Поган & Поган \\
\hline
\end{tabular}

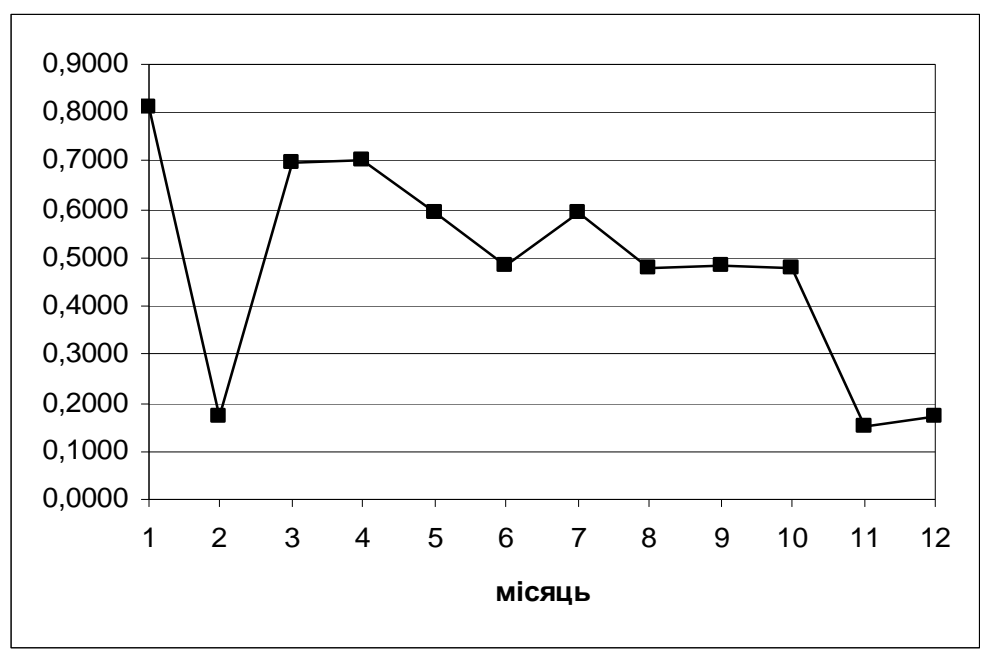

Рис.1 Значення інтегрального показника на протязі року

Проведемо аналіз отриманих значень інтегрального показника, з'ясуємо, які фактори на них вплинули у вигляді таблиці, де символом “+” позначено позитивний вплив, а символом “-” негативний вплив.

Таблиця 13

Аналіз інтегрального показника

\begin{tabular}{|c|c|c|c|c|c|c|c|c|c|c|c|c|c|}
\hline & \multicolumn{10}{|c|}{ Місяці } \\
\hline & I & II & III & IV & V & VI & VII & VIII & IX & X & XI & XII \\
\hline $\mathrm{q}_{1}$ & - & + & + & + & + & + & + & + & + & + & + & + \\
\hline $\mathrm{q}_{2}$ & + & + & + & + & + & + & + & + & + & + & + & + \\
\hline $\mathrm{q}_{3}$ & + & + & + & + & + & + & + & + & + & + & + & + \\
\hline $\mathrm{q}_{4}$ & - & + & + & + & + & + & + & + & + & + & + & + \\
\hline $\mathrm{q}_{7}$ & + & + & + & + & + & + & + & + & + & + & + & + \\
\hline $\mathrm{q}_{8}$ & - & - & - & + & - & + & - & + & + & + & - & - \\
\hline $\mathrm{q}_{10}$ & - & - & + & + & + & + & + & + & + & + & - & - \\
\hline $\mathrm{q}_{11}$ & - & - & - & - & - & + & - & + & + & + & - & - \\
\hline $\mathrm{q}_{12}$ & + & + & + & + & + & + & + & + & + & + & + & - \\
\hline $\mathrm{q}_{13}$ & - & - & - & - & - & - & - & - & + & + & - & - \\
\hline $\mathrm{Q}$ & 1,685 & $-0,704$ & 0,8079 & 0,8112 & 0,702 & 0,486 & 0,590 & 0,47 & 0,48 & 0,48 & 0,15 & $-0,16$ \\
\hline Стан & Поган & Поган & Задов. & Задов. & Задов. & Доб & Задов. & Доб & Доб & Доб & Поган & Поган \\
\hline
\end{tabular}

Аналіз Табл. 13 показує, що добрий стан наявності фінансових ресурсів для забезпечення життєдіяльності ЗС України, це коли ні один фактор негативно не впливає на результат (IX, $\mathrm{X)} \mathrm{або} \mathrm{тільки} \mathrm{один} \mathrm{(VI,} \mathrm{VIII),} \mathrm{задовільний} \mathrm{стан} \mathrm{-}$ це коли окремі показники (2 або 3) впливають негативно (III, IV, V, VII), поганий стан - це коли більш трьох показників впливають негативно (I, II, XI, XII). Найбільш негативний вплив при цьому сценарії оказують коефіцієнт виконання кошторису загального фонду $\left(q_{8}\right)$, відносні показники відхилення суми фактичного 
фінансування від планового $\left(q_{11}\right)$ та суми кошторисних призначень від суми потреби $\left(q_{13}\right)$. За рахунок відносного показника відхилення суми фактичного фінансування від планового можна отримати негативні значення (перефінансування).

Висновки. Таким чином, запропоновані ключові показники ефективності фінансового забезпечення Збройних Сил України адекватно відображають стан наявності фінансових ресурсів для забезпечення життєдіяльності ЗС України, що дає змогу в подальшому створити основу для забезпечення інформаційноаналітичної підтримки процесу прийняття управлінських рішень та запровадження системи внутрішнього контролю та управління ризиками у сфері фінансового забезпечення Збройних Сил України.

Напрямки подальших досліджень. Одним з питань при використанні інтеграційних показників $є$ якісне трактування отриманих значень (“погано”, “задовільно”, “добре”), визначення границь та меж неоднозначності між якісними оцінками, що потребує подальших досліджень.

\section{СПИСОК ВИКОРИСТАНОЇ ЛІТЕРАТУРИ}

1. Мунтіян В. Фінансування Збройних Сил України: проблеми та перспективи // Дзеркало тижня. - 2002. - № 34. - c. 4-6.

2. Мунтіян B.I. Оборонний бюджет: світовий досвід та можливі шляхи реформування в
Україні. Монографія. - К.: Просвіта, 1996. - 240 с.

3. Мунтіян B.I. Економіка та оборонні витрати: аналіз зарубіжних досліджень і український шлях розвитку. Монографія - К.: НДФІ, 1998. - 464 с.

4. Васильченко 3.М. Бюджетне планування видатків на утримання особового складу Збройних сил України / 3.М. Васильченко, С.М. Чімишенко // Фінанси України. - 2010. - № 5.

5. Запатріна I.B. Програмно-цільовий метод бюджетування у контексті стратегічного та середньострокового планування / I.B. Запатріна, Т.Б. Лебеда // Фінанси України. - 2006. - № 10.

6. Ващенко I. В. Система ключових показників ефективності фінансового забез-печення Збройних Сил України / Ткаченко М. В., Федоренко Р. М., Педан Ф. П., Руденська Г. В. Збірник наукових праць ЦВСД НУОУ № 1 (56), 2016 р., с. 126-129. Київ

7. Степанюк М.Ю. Багаторівнева адитивномультиплікативна модель оцінки узагальнених показників при стратегічному управлінні на основі системи збалансованих показників / М.Ю. Степанюк // Проблеми програмування. - 2010. - № 1. - c. $108-115$.

8. Степанюк М.Ю. Поход к стратегическому планированию на основе системы сбалансированных показателей с использованием многоуровневой модели оценки / М.Ю. Степанюк, И.П. Синицын // Матеріали міжнар. наук. конф. “Моделювання 2010": зб. наук. праць, (Київ, 12-14 травня 2010). - Київ: ІПМЕ НАН України, 2010. T. 3. - c. $166-171$.

Стаття надійшла до редакції 15.03.2017

Руденская Г. В.;

Педан Ф. Ф.;

Ткаченко М. В., к.т.н.

Центр военно-стратегических исследований Национального университета обороны Украины имени Ивана Черняховского, Киев

\section{Использование системы ключевых показателей при оценке финансового обеспечения Вооруженных Сил Украины}

Резюме. На основе тестовых данных проведен расчет интегрального показателя для оценки финансово-экономической деятельности Вооруженных Сил Украины и дана качественная интерпретация полученным результатам.

Ключевые слова: ключевые показатели, аддитивно-мультипликативная модель, интегральный показатель, оценка, финансово-экономическая деятельность.

\section{G. Rudenska;}

F. Pedan;

M. Tkachenko, Ph.D

Center for Military and Strategic Studies National Defence University of Ukraine named after Ivan Chernyhovsky, Kyiv

Using of the system of key indexes for the estimation of the financial providing of the Armed Forces of Ukraine

Resume. Based on the test data the calculation of the integral indicator to assess the financial-economic activities of the Armed Forces of Ukraine and the qualitative interpretation of the obtained results.

Keywords: key indicators, additive-multiplicative model, integrated indicator, assessment, financialeconomic activity. 